\title{
Pension sharing in Scotland: general principles in the Family Law (Scotland) Act 1985?
}

Alan Brown

This is an Accepted Manuscript of an article published by Taylor \& Francis in Journal of Social Welfare and Family Law on 6th March 2018, available online:

wwww.tandfonline.com/10.1080/09649069.2018.1414395 


\title{
Pension Sharing in Scotland: General Principles in the Family Law (Scotland)
} Act 1985?

\author{
Dr Alan Brown, Lecturer in Law, Division of Law, Abertay University, \\ Scotland, UK. \\ Email: a.brown@abertay.ac.uk
}

Keywords: Financial provision on divorce; pensions; Scotland; statutory interpretation

McDonald v McDonald [2017] UKSC 52 is significant as the first occasion on which the Supreme Court has given a judgment on any aspect of the Family Law (Scotland) Act 1985 ('the 1985 Act'). Specifically, the Supreme Court sought to apportion a pension fund by determining how much could be considered 'matrimonial property' and susceptible to distribution on divorce.

It is a core principle of the 1985 Act that spouses' 'matrimonial property' is 'shared fairly', s.9 (1) (a). This is defined by s. 10 (4) as all property acquired during the marriage excluding gifts or inheritance. Pursuant to s.10 (5) the benefits acquired under a pension arrangement during the marriage will also constitute matrimonial property. In addition, the valuation and apportionment of interests in pensions considered to be matrimonial property is governed by subordinate legislation; the Divorce etc. (Pensions) (Scotland) Regulations 2000 ('the 2000 Regulations').

The McDonalds married in March 1985 and ceased cohabiting in September 2010. The husband was employed as a miner by British Coal, and began contributing to the British Coal Staff Superannuation Scheme ('the pension scheme') in December 1978. Shortly after the parties married, the husband suffered a severe leg injury. Consequently he retired on the grounds of ill-health and began receiving an income from the pension scheme in August 1985 (para. 2).

The cash equivalent transfer value ('CETV') of the husband's pension on the relevant date was $£ 172,748.38$. The dispute concerned the interpretation of the formula, found in regulation 4 of the 2000 Regulations, for apportioning the CETV to determine how much is considered 'matrimonial property' in terms of s.10 (5). The dispute focused on a clause within the formula 
which refers to 'the period of the membership of that party in the pension arrangement before the relevant date'. The Supreme Court had to determine whether the term 'membership' within regulation 4 referred only to the husband's 'active membership' (a term taken from s.124 of the Pensions Act 1995) of the pension scheme, which ended in August 1985, or to the entire period of his membership, including the years in which he received a benefit under the pension scheme, which ended in September 2010 (para. 6). Spier (2017, pg. 2) described the 'active membership' approach as '[t]he conventional view among practitioners', but if this approach was applied in McDonald, the value to be distributed would be just $£ 10,002$, compared with a value of $£ 138,354$ if the broader interpretation was preferred.

At first instance (TCM v AFMM 2014 Fam. L.R. 11), Sheriff Holligan held that 'membership' in regulation 4 should be understood as 'active membership' and only $£ 10,002$ would constitute matrimonial property. His approach was based upon his reading of the wording of the formula in regulation 4, and what he described as consistency with the 'general principles' of the 1985 Act, particularly the terms of s.10 (4) that 'matrimonial property' should generally be limited to property acquired during the marriage before the relevant date. The wife appealed to the Inner House of the Court of Session (McDonald v McDonald [2015] CSIH 61); the appeal was dismissed by a majority of an Extra Division (with Lady Smith dissenting). In upholding the Sheriff's decision, Lord Malcolm (with whom Sheriff Principal Abercrombie agreed) stated that in relation to the provisions of the 1985 Act and the 2000 Regulations he preferred to adopt 'a purposive construction which avoids results going against the grain of the Act and the underlying legislative purpose' (para. 40) and so the 'active membership' approach was to be followed.

The Supreme Court allowed the appeal, which meant the value of the husband's pension that constituted matrimonial property was $£ 138,534$ and the wife could seek a pension sharing order over this amount. Lord Hodge (with whom the other Justices agreed) stated that there were four reasons for preferring the wider interpretation of 'membership' in regulation 4 to the interpretation adopted by the Sheriff and affirmed by the Inner House (para. 25). The first reason was the most straightforward; the definition of 'membership' as 'active membership' involved, 'adding words to regulation 4 which are not there' (para.26). The second reason built on that simple statement of statutory construction, with the judgment noting that it was not disputed between the parties that the 2000 Regulations apply to different forms of pension schemes. However, the interpretation of the regulation taken by the Inner House only made 
sense in relation to occupational pension schemes; it did not make sense for personal pension schemes, nor relevant state pension schemes. This disjuncture prompted Lord Hodge to observe that, '[i]t is to be assumed that Parliament intended the provisions of the regulations to operate sensibly in relation to the differing pension schemes and state pension rights' (para. 27).

The third reason for the wider interpretation of 'membership' involved a rejection of the argument made in the lower courts that a 'purposive' interpretation of regulation 4 was justified by reference to the 'general principles' of the 1985 Act and particularly the terms of s.10 (4). Lord Hodge noted that s.10 (4) and s.10 (5) are drafted so that interests in pensions are defined separately from other 'matrimonial property', observing, 'the opening words of section 10(4) carve subsection (5) out of the section 10(4) definition of matrimonial property. Parliament chose to deal with pension rights differently by making discrete provision for them' (para.28). This interpretation of s.10 (4) and s.10 (5), which places considerable significance on the words 'subject to' in s.10 (4), appears to be central to the reasoning of the Supreme Court judgment. However, as well as identifying this separation within the legislative regime between pensions and other matrimonial property, the judgment questions the Inner House's identification of such a 'general principle' within the 1985 Act, with Lord Hodge commenting: 'It is thus difficult to detect a general principle confining matrimonial property to assets acquired during the marriage to support the purposive interpretation which the majority of the Extra Division has favoured' (para. 29).

The fourth reason was the most technical, and related to the operation of the formula within regulation 4. In short, this formula refers to the potential of a value to be zero, and in the lower courts significant weight was placed on the idea that the wider definition of 'membership' would render it impossible for this value to be zero, whereas the 'active membership' interpretation would give meaning to this part of the formula. However, the lower courts' view was rejected by the Supreme Court, on the basis of the clear wording of the 2000 Regulations, with Lord Hodge stating, "[i]f the person drafting the wording...intended it to confine "membership" to "active" membership that would involve egregious circumlocution. There is no hint of such intention in the words of the Regulations' (para. 30).

In this way, all four of the reasons given in judgment amount to a reasserting of a strict and literal approach to statutory interpretation, in the context of regulation 4 and s.10 of the 1985 Act, rejecting the purposive approach adopted by the lower courts. Therefore, the Supreme 
Court judgment in McDonald could simply be seen as a relatively uncontroversial restatement of basic principles of statutory interpretation, in circumstances where the lower courts had seemingly gone beyond the ordinary understanding of the judicial function in their approach. However, the judgment potentially has wider significance than this specific issue of statutory interpretation, because in overturning the decision of the Inner House, the judgment appears to question the assumptions of the Inner House about the general principles of the 1985 Act, or indeed the very suggestion that such general principles exist. These are 'principles' which appeared to represent the accepted and uncontroversial understanding of the legislation prior to McDonald, as seen by Lord Malcolm's reference to 'the underlying legislative purpose'. Thus, it remains to be seen whether this decision will have any further implications for the interpretation of the 1985 Act, and whether the Supreme Court will have another occasion to consider financial provision on divorce in Scotland. Indeed, prior to McDonald, it had been over 20 years since Jacques v Jacques 1997 Fam L.R. 3, the most recent House of Lords decision on any aspect of the 1985 Act.

Regardless of these wider considerations, the impact of the McDonald decision will be substantial for divorcing couples in Scotland, because the judgment fundamentally alters the method through which pensions will be valued within financial provision on divorce.

\section{References}

Spier, J. (2017). Pensions after McDonald v McDonald - when B changed from being a zero to a potential special circumstance. Family Law Bulletin, 149, 1-5. 